\title{
PEMAHAMAN MENGENAI PRODUKSI DAN TINGKAT EFISIENSI TEKNIS CABAI MERAH DI KABUPATEN BANGKA TENGAH
}

\author{
Rati Purwasih $^{1}$, Novyandra Ilham Bahtera ${ }^{1 *}$, Yulia ${ }^{1}$ \\ ${ }^{1}$ Jurusan Agribisnis, Universitas Bangka Belitung \\ * Email: novyandra.ib@gmail.com
}

\begin{abstract}
ABSTRAK: Produktivitas cabai merah di Kabupaten Bangka Tengah masih tergolong rendah. Hal ini dapat terlihat dari nilai produktivitas cabai merah di kabupaten ini masih berada jauh di bawah potensi genetis cabai merah keriting yaitu 35.6 kuintal per hektar, sedangkan potensi genetis cabai merah keriting sebesar 200-220 kuintal per hektar. Kondisi ini menimbulkan dugaan bahwa usahatani cabai merah di Kabupaten Bangka Tengah belum efisien secara teknis. Penelitian ini bertujuan untuk menganalisis faktor-faktor yang mempengaruhi produksi cabai merah, tingkat efisiensi teknis usahatani cabai merah dan faktor-faktor yang menyebabkan inefisiensi teknis usahatani cabai merah bagi petani yang mengikuti program peningkatan produktivitas pertanian di Kabupaten Bangka Tengah. Metode penelitian yang digunakan yaitu metode survei. Metode penarikan sampel yaitu sampling jenuh. Kriteria responden yaitu petani yang berusahatani cabai merah serta telah mengikuti program peningkatan produktivitas pertanian di Kabupaten Bangka Tengah, dengan jumlah 43 orang. Metode analisis data yang digunakan yaitu model fungsi produksi stochastic frontier, dengan metode Maximum Likelihood Estimated (MLE). Hasil analisis menunjukkan faktor-faktor yang mempengaruhi produksi cabai merah petani yang mengikuti program peningkatan produktivitas pertanian di Kabupaten Bangka Tengah yaitu benih, tenaga kerja, insektisida dan kapur. Usahatani cabai merah petani yang mengikuti Program tersebut tidak efisien secara teknis. Ini terlihat dari rata-rata nilai efisiensi teknisnya sebesar 0.54. Kondisi ini mengindikasikan bahwa petani belum optimal menggunakan faktor produksi pada usahatani cabai merah. Faktor yang menyebabkan usahatani cabai merah petani yang mengikuti Program tersebut tidak efisien secara teknis yaitu frekuensi mengikuti penyuluhan cabai merah dan pendidikan petani.
\end{abstract}

Kata Kunci: Efisiensi Teknis; Keberlanjutan; Kedaulatan Pangan; Petani Cabai Merah

\section{PENDAhUluan}

Salah satu sektor ekonomi yang penting sebagai sumber pendapatan dan penyedia lapangan usaha bagi masyarakat adalah sektor pertanian (Anggraini 2015). Hal ini terlihat dari besarnya sumbangan yang diberikan oleh sektor pertanian terhadap Produk Domestik Bruto (PDB). PDB berdasarkan harga berlaku menurut lapangan usaha pada tahun 2018 menunjukkan bahwa sektor pertanian menempati urutan kedua yang menyumbang laju pertumbuhan ekonomi di Indonesia yaitu sebesar 12,81 persen dari total PDB Indonesia selama tahun 2018 (BPS 2019).

Sektor pertanian terdiri atas beberapa sub sektor yaitu sub sektor tanaman pangan, hortikultura, perkebunan, peternakan, kehutanan, dan perikanan. Berdasarkan data BPS tahun 2019, sub sektor tanaman hortikultura memberikan sumbangan yang terbilang besar terhadap 
PDB sektor pertanian di Indonesia yaitu sebesar 1,47 persen dari 12,81 persen PDB sektor pertanian. Salah satu komoditas sub sektor hortikultura adalah cabai merah.

Berdasarkan Keputusan Menteri Pertanian Nomor 830/Kpts/RC.040/12/2016 menetapkan Lokasi Pengembangan Kawasan Pertanian Nasional. Salah satu provinsi di Indonesia yang ditetapkan sebagai Lokasi Pengembangan Kawasan Pertanian Nasional Komoditas Prioritas Hortikultura khususnya komoditas cabai yaitu provinsi Kepulauan Bangka Belitung, khususnya di Kabupaten Belitung dan Kabupaten Bangka Tengah (Kepementan 2016).

Sebagai bentuk pelaksanaan terhadap kebijakan pemerintah mengenai penetapan Lokasi Pengembangan Kawasan Pertanian Nasional Komoditas Prioritas Hortikultura khususnya komoditas cabai tersebut, maka oleh pemeritah Kabupaten Bangka Tengah dijabarkan ke dalam Program Peningkatan Produktivitas Pertanian. Program ini terbilang masih baru karena mulai dilaksanakan pada Bulan September 2017. Tujuan program ini yaitu untuk menekan inflasi dan mendorong kesejahteraan petani khususnya petani cabai merah sehingga dapat mempercepat pembangunan daerah (Widyastuti 2018). Keberhasilan program ini akan sangat mempengaruhi produktivitas cabai merah yang akan dicapai. Produksi, luas panen, dan produktivitas cabai merah yang dicapai Kabupaten Bangka Tengah dapat dilihat pada Tabel 1 .

Tabel 1. Produksi, Luas Panen, dan Produktivitas Cabai Merah di Kabupaten Bangka Tengah, Januari - Agustus 2017

\begin{tabular}{clccc}
\hline No & \multicolumn{1}{c}{ Kecamatan } & $\begin{array}{c}\text { Produksi } \\
\text { (kuintal) }\end{array}$ & Luas Panen (ha) & $\begin{array}{c}\text { Produktivitas } \\
\text { (kuintal/ha) }\end{array}$ \\
\hline 1 & Koba & 40 & 2,21 & 18,19 \\
2 & Pangkalan Baru & 491 & 15,15 & 32,41 \\
3 & Sungaiselan & 190 & 8,03 & 23,66 \\
4 & Simpangkatis & 313 & 4,60 & 68,04 \\
5 & Namang & 120 & 2,00 & 60,00 \\
6 & Lubuk besar & 200 & 6,05 & 33,06 \\
\hline & Total & 1.354 & 38,04 & 35,60 \\
\hline
\end{tabular}

Sumber: Dinas Pertanian Provinsi Kepulauan Bangka Belitung (2017)

Produktivitas cabai merah di Kabupaten Bangka Tengah pada tahun 2017 yaitu 35.6 kuintal per hektar (Tabel 1). Hal ini menunjukkan produktivitas cabai merah di kabupaten ini masih tergolong rendah karena masih berada jauh di bawah potensi genetis cabai merah keriting yaitu 200-220 kuintal per hektar. Kondisi ini menimbulkan dugaan bahwa usahatani cabai merah di kabupaten ini belum efisien secara teknis. Permasalahan masih rendahnya produktivitas cabai merah di Kabupaten Bangka Tengah ini diduga karena petani belum optimal mengalokasikan faktor-faktor produksi (input) di dalam usahataninya dan kemampuan petani mengelola usahatani juga belum memadai.

Selain itu, belum efisiennya suatu usahatani secara teknis juga dipengaruhi oleh karakteristik sosial ekonomi petani. Hal ini mengindikasikan bahwa belum efisiennya usahatani cabai merah secara teknis di Kabupaten Bangka Tengah juga dipengaruhi oleh karakteristik sosial ekonomi petani. Anggaraini (2015) menyatakan bahwa tingkat efisiensi usahatani ubi kayu selain dipengaruhi oleh kombinasi penggunaan input, juga dipengaruhi oleh karakteristik yang ada dalam diri petani. Sumber-sumber penyebab inefisiensi antara lain umur, pengalaman berusahatani, ukuran rumah tangga, tingkat pendidikan, keanggotaan kelompok tani, penyuluhan, akses kredit, dan lainnya. Karakteristik sosial tersebut mempengaruhi kemampuan manajerial petani di dalam memproduksi ubi kayu, sehingga 
akan mempengaruhi tingkat efisiensi usahatani ubi kayu. Anggraini (2016) menyatakan bahwa peningkatan efisiensi dipengaruhi oleh teknik budidaya, faktor-faktor produksi yang digunakan serta faktor sosial ekonomi petani. Oleh sebab itu, peningkatan produktivitas cabai merah melalui efisiensi teknis penting untuk diperhatikan.

\section{EFISIENSI PRODUKSI}

Efisiensi produksi dalam usahatani erat kaitannya dengan tingkat keuntungan maksimum yang dicapai petani. Terdapat dua hal yang menyebabkan proses produksi menjadi tidak efisien yaitu (1) tidak efisien secara teknis karena ketidakberhasilan di dalam mencapai produktivitas yang maksimal artinya setiap input per unit tidak dapat menghasilkan produksi maksimal, (2) tidak efisien secara alokatif karena pada tingkat harga-harga input dan output tertentu, proporsi penggunaan input tidak optimum karena penerimaan produk marjinal tidak sama dengan biaya marjinal dari input yang digunakan (Ellis, 2003; Saptana et al,. 2010).

Unsur-unsur pokok yang tercakup dalam aplikasi teknologi yaitu input apa saja yang digunakan dalam usahatani, berapa banyak, kapan, berapa kali, dan metode apa yang digunakan dalam berproduksi. Kapabilitas manajerial pada akhirnya akan tercermin dari output yang dihasilkan pada saat hasil tanaman yang dibudidayakan sudah dipanen. Petani dapat dikatakan telah mengelola usahataninya dengan efisien yang tinggi jika produksi yang dicapai mendekati potensi maksimum (Saptana et al. 2010).

Kapabilitas manajerial yang dimiliki oleh seorang petani dalam budidaya cabai merah tercermin dalam aplikasi tekonologi usahatani, yang sangat ditentukan oleh pendidikan dalam pengalaman petani dalam berusahatani (Saptana et al. 2010). Semakin tinggi tingkat pendidikan petani, maka pemikirannya akan semakin bertambah luas terhadap suatu inovasi baru. Artinya petani yang berpendidikan tinggi akan lebih mudah menerima, menerapkan dan bahkan mengembangkannya dibandingkan dengan petani yang berpendidikan rendah. Selain itu, pengalaman berusahatani merupakan salah satu faktor yang dapat menunjang dalam meningkatkan kemampuan kerja petani dalam berusahatani (Gusmawati et al. 2014). Semakin lama pengalaman yang dimiliki oleh seorang petani dalam berusahatani hingga batas umur tertentu, maka keterampilan teknis dan kapabilitas manajerialnya akan semakin tinggi (Saptana et al. 2010).

\section{METODE}

Penelitian dilaksanakan di Desa Belilik, Desa Sungkap, Desa Keretak dan Desa Trubus dimana ke empat desa tersebut berada di Kabupaten Bangka Tengah. Penelitian dilakukan secara sengaja (purposive) dengan pertimbangan bahwa Kabupaten Bangka Tengah merupakan salah satu Lokasi Pengembangan Kawasan Pertanian Nasional Komoditas Prioritas Hortikultura khususnya komoditas cabai di Provinsi Kepulauan Bangka Belitung. Ke empat desa tersebut merupakan desa yang melaksanakan Program Peningkatan Produktivitas Pertanian. Penelitian dilaksanakan mulai dari Maret 2019 sampai dengan Agustus 2019.

Metode penelitian yang digunakan yaitu metode survei. Metode penarikan sampel yang digunakan yaitu purposive sampling. Kriteria petani yang akan menjadi responden penelitian yaitu petani cabai merah yang mengikuti Program Peningkatan Produktivitas Pertanian.

Alat analisis yang digunakan untuk menjawab tujuan penelitian yaitu frontier. Adapun fungsi produksi cabai merah yang dianalisis yaitu menggunakan fungsi produksi bertipe Cobb-Douglas, dengan pendekatan stokastik frontier dengan metode maximum likelihood estimated (MLE). Berikut persamaan matematis dari fungsi produksi tersebut (Coelli at al., 1998): 


$$
\begin{aligned}
\ln \mathrm{y}= & \beta_{0}+\beta_{1} \ln \mathrm{x}_{1}+\beta_{2} \ln \mathrm{x}_{2}+\beta_{3} \ln \mathrm{x}_{3}+\beta_{4} \ln \mathrm{x}_{4}+\beta_{5} \ln \mathrm{x}_{5}+\beta_{6} \ln \mathrm{x}_{6}+\beta_{7} \ln \mathrm{x}_{7}+ \\
& \beta_{8} \ln \mathrm{x}_{8}+\left(\mathrm{v}_{\mathrm{i}}-\mathrm{u}_{\mathrm{i}}\right)
\end{aligned}
$$

Keterangan :

$\mathrm{y}=$ Produksi cabai merah $(\mathrm{Kg})$

$\mathrm{x}_{1}=$ Jumlah benih cabai merah (Gram)

$\mathrm{x}_{2}=$ Jumlah tenaga kerja (HKP)

$\mathrm{x}_{3}=$ Jumlah pupuk $\mathrm{N}(\mathrm{kg})$

$\mathrm{x}_{4}=$ Jumlah pupuk $\mathrm{P}(\mathrm{kg})$

$\mathrm{x}_{5}=$ Jumlah pupuk $\mathrm{K}(\mathrm{kg})$

$\mathrm{x}_{6}=$ Jumlah insektisida (liter)

$\mathrm{x}_{7}=$ Jumlah fungisida $(\mathrm{Kg})$

$\mathrm{x}_{8}=$ Jumlah kapur $(\mathrm{Kg})$

$\mathrm{v}_{\mathrm{i}}=$ error term menunjukkan ketidakpastian produksi yang diasumsikan i.i.d $(0, \sigma \mathrm{v})^{2}$

$\mathrm{u}_{\mathrm{i}}=$ menunjukkan inefisiensi teknis dengan asumsi i.i.d $(0, \sigma u)^{2}$ dan $\mathrm{u}>0$, ui independen terhadap vi.

Nilai koefisien regresi yang diharapkan : $\beta_{1}, \beta_{2}, \beta_{3}, \beta_{4}, \beta_{5}, \beta_{6}, \beta_{7}, \beta_{8}>0$

Tingkat efisiensi teknis dapat dihitung dengan menggunakan rumus sebagai berikut

(Coelli at al. 1998):

$$
\mathrm{TE}_{\mathrm{i}}=\frac{\mathrm{y}_{\mathrm{i}}}{\exp \left(\mathrm{x}_{\mathrm{i}} \beta\right)}=\frac{\exp \left(\mathrm{x}_{\mathrm{i}} \beta-\mathrm{u}_{\mathrm{i}}\right)}{\exp \left(\mathrm{x}_{\mathrm{i}} \beta\right)}=\exp \left(-\mathrm{u}_{\mathrm{i}}\right)
$$

Sumber-sumber penyebab terjadinya inefisiensi teknis dianalisis menggunakan persamaan berikut (Coelli at al, 1998):

$\mathrm{U}_{\mathrm{i}}=\delta_{0}+\delta_{1} \mathrm{z}_{1}+\delta_{2} \mathrm{z}_{2}+\delta_{3} \mathrm{z}_{3}+\delta_{4} \mathrm{z}_{4}+\delta_{5} \mathrm{z}_{5}+\delta_{6} \mathrm{z}_{6}$

$\mathrm{U}_{\mathrm{i}}=$ Nilai efsiensi teknis

$\mathrm{z}_{1}=$ Umur petani (tahun)

$\mathrm{Z}_{2}=$ Pendidikan petani (tahun)

$\mathrm{Z}_{3}=$ Pengalaman petani dalam berusahatani cabai merah (tahun)

$\mathrm{Z}_{4}=$ Rasio jumlah anggota rumah tangga usia kerja terhadap total anggota rumah tangga

$\mathrm{z}_{5}=$ Frekuensi mengikuti penyuluhan tentang cabai merah (kali)

$\mathrm{z}_{6}=$ Frekuensi mengikuti pertemuan kelompok tani (kali)

\section{HASIL DAN PEMBAHASAN}

Hasil dari penelitian ini mencakup pembahasan mengenai analisis fungsi produksi, efisiensi teknik dan faktor penyebab inefisiensi teknis usahatani cabai merah di Kabupaten Bangka Tengah.

\subsection{Analisis Fungsi Produksi Usahatani Cabai Merah di Kabupaten Bangka Tengah}

Dalam proses produksi suatu komoditas usahatani memerlukan input atau faktor produksi. Tinggi rendahnya jumlah produksi suatu komoditas usahatani tidak terlepas dari peranan penting faktor produksi atau input yang digunakan. Oleh karena itu input yang diduga mempengaruhi besar kecilnya produksi cabai merah petani yang mengikuti program peningkatan produktivitas pertanian di Kabupaten Bangka Tengah di antaranya benih, tenaga kerja, pupuk $\mathrm{N}$, pupuk $\mathrm{P}$, pupuk $\mathrm{K}$, insektisida, fungisida, dan kapur. Untuk memastikan apakah keseluruhan input tersebut mempengaruhi besar kecilnya produksi cabai merah maka dilakukan analisis Stochastic Frontier Production Function. Hasil pendugaan tersebut dapat dilihat pada Tabel 2. 
Tabel 2. Hasil Pendugaan Stochastic Frontier Production Function pada Usahatani Cabai Merah di Kabupaten Bangka Tengah

\begin{tabular}{|c|c|c|c|}
\hline Variabel & Coefficient & Std.Error & t-ratio \\
\hline Benih & $-0,3507$ & 0,1769 & $-1,9819^{b}$ \\
\hline Tenaga kerja & 0,3621 & 0,0354 & $10,2152^{\mathrm{a}}$ \\
\hline Pupuk N & 0,1806 & 0,1252 & 1,4431 \\
\hline Pupuk K & $-0,1394$ & 0,1438 & $-0,9690$ \\
\hline Insektisida & 0,5315 & 0,1630 & $3,2607^{\mathrm{a}}$ \\
\hline Fungisida & 0,0701 & 0,0673 & 1,0407 \\
\hline Kapur & 0,4123 & 0,1397 & $2,9523^{\mathrm{a}}$ \\
\hline Sigma-squared & 0,2571 & & \\
\hline Gamma & 0,9999 & & \\
\hline Log likelihood function & $-35,0337$ & & \\
\hline LR test of the one-sided error & 28,8282 & & \\
\hline
\end{tabular}

Ket: ${ }^{a}$ signifikan pada taraf $1 \%$, ${ }^{\text {s }}$ signifikan pada taraf $10 \%$

Berdasarkan hasil pendugaan dengan metode MLE pada Tabel 2, terdapat empat dari tujuh variabel yang dianalisis berpengaruh nyata secara statistik terhadap produksi cabai merah di Kabupaten Bangka Tengah sampai pada taraf nyata $10 \%$ yaitu benih, tenaga kerja, insektisida, dan kapur. Sementara itu, pupuk N, pupuk K dan fungisida tidak berpengaruh nyata secara statistik sampai pada taraf nyata $10 \%$.

\subsection{Efisiensi Teknis Usahatani Cabai Merah di Kabupaten Bangka Tengah}

Hasil analisis efisiensi pada usahatani cabai merah menghasilkan nilai efisiensi teknis maksimum sebesar 0.99 dan minimum 0.03. Rata-rata nilai efisiensi teknis usahatani cabai merah yaitu sebesar 0.54 . Selengkapnya mengenai nilai efisiensi teknis pada usahatani cabai merah dapat dilihat pada Tabel 3.

Tabel 3. Sebaran Nilai Efisiensi Teknis Usahatani Cabai Merah di Kabupaten Bangka Tengah

\begin{tabular}{|c|c|c|}
\hline Sebaran Efisiensi & $\begin{array}{r}\text { Jumlah } \\
\text { (Orang) }\end{array}$ & $\begin{array}{c}\text { Persentase } \\
(\%)\end{array}$ \\
\hline$<0.50$ & 17 & 42.5 \\
\hline $0.50 \leq \mathrm{TE} \leq 0.59$ & 3 & 7.5 \\
\hline $0.60 \leq \mathrm{TE} \leq 0.69$ & 6 & 15 \\
\hline $0.70 \leq \mathrm{TE} \leq 0.79$ & 4 & 10 \\
\hline $0.80 \leq \mathrm{TE} \leq 0.89$ & 2 & 5 \\
\hline $0.90 \leq \mathrm{TE} \leq 0.99$ & 8 & 20 \\
\hline Jumlah & 40 & 100 \\
\hline Maksimum & \multicolumn{2}{|c|}{0.99} \\
\hline Minimum & \multicolumn{2}{|c|}{0.03} \\
\hline Rata-rata & \multicolumn{2}{|c|}{0.54} \\
\hline
\end{tabular}

Berdasarkan Tabel 3, usahatani cabai merah di Kabupaten Bangka belum efisien secara teknis. Hal ini dapat dilihat dari nilai rata-rata efisiensi teknis usahatani cabai merah yaitu sebesar 0.54. Dikatakan efisien apabila nilai efisiensi teknis $\geq 0.7$ dan dikatakan belum efisien apabila nilai efisiensi teknis $<0.7$. Nilai ini menunjukkan bahwa pada tingkat input 
dan teknologi yang ada, rata-rata peluang petani cabai merah yang mengikuti program peningkatan produktivitas pertanian di Kabupaten Bangka Tengah untuk meningkatkan produksi cabai merah yaitu sebesar $45.94 \%$. Sebaran nilai efisiensi teknis usahatani cabai merah yang dominan berada pada interval $<0.5$ yaitu sebanyak $42.5 \%$ atau 17 orang. Petani cabai merah yang memiliki nilai efisiensi teknis pada interval $0.90 \leq \mathrm{TE} \leq 0.99$ hanya $20 \%$ atau delapan orang.

\subsection{Faktor Penyebab Inefisiensi Teknis Usahatani Cabai Merah di Kabupaten Bangka Tengah}

Inefisiensi teknis usahatani cabai merah diduga dipengaruhi oleh faktor internal atau faktor dari dalam diri petani. Faktor internal yang diduga mempengaruhi inefisiensi teknis usahatani cabai merah di Kabupaten Bangka Tengah antara lain umur petani, pendidikan petani, pengalaman petani dalam berusahatani cabai merah, rasio jumlah anggota rumah tangga usia kerja terhadap total anggota rumah tangga petani, frekuensi mengikuti penyuluhan, dan frekuensi mengikuti pertemuan kelompok tani. Hasil dugaan efek inefisiensi teknis usahatani cabai merah di Kabupaten Bangka Tengah dapat dilihat pada Tabel 4.

Tabel 4. Hasil Dugaan Efek Inefisiensi Teknis Usahatani Cabai Merah di Kabupaten Bangka

Tengah

\begin{tabular}{lrrc}
\hline \multicolumn{1}{c}{ Variabel } & Coefficient & Std.Error & t-ratio \\
\hline Umur petani & -0.03 & 0.04 & -0.7 \\
Pendidikan petani & 0.19 & 0.11 & $1.74^{\mathrm{b}}$ \\
Pengalaman berusahatani & 0.04 & 0.09 & 0.33 \\
Rasio jumlah anggota RT usia kerja terhadap total & -0.37 & 1.02 & -0.36 \\
aggota RT & & & \\
Frekuensi mengikuti penyuluhan & -0.61 & 0.32 & $-1.95^{\mathrm{b}}$ \\
Frekuensi mengikuti pertemuan kelompok tani & -0.02 & 0.079 & -0.30 \\
\hline
\end{tabular}

Keterangan: ${ }^{b}$ signifikan pada taraf $10 \%$

\section{KESIMPULAN}

Faktor-faktor produksi yang berpengaruh nyata terhadap produksi cabai merah petani yang mengikuti Program Peningkatan Produktivitas Pertanian di Kabupaten Bangka Tengah yaitu benih, tenaga kerja, insektisida, dan kapur, sedangkan pupuk N, pupuk K dan fungisida tidak berpengaruh nyata. Usahatani cabai merah petani cabai merah yang mengikuti Program Peningkatan Produktivitas Pertanian di Kabupaten Bangka Tengah belum efisien secara teknis, di mana rata-rata nilai efisiensi teknis yang diperoleh yaitu sebesar 0.54. Selanjutnya, faktor yang meningkatkan inefisiensi teknis usahatani cabai merah petani yang mengikuti Program Peningkatan Produktivitas Pertanian di Kabupaten Bangka Tengah yaitu pendidikan petani, sedangkan faktor yang menurunkan inefisiensi teknis yaitu frekuensi megikuti penyuluhan pertanian

\section{UCAPAN TERIMA KASIH}

Ucapan terima kasih disampaikan kepada Kemeterian Riset dan Teknologi Pendidikan Tinggi yang telah mendukung secara moril dan materil pada penelitian ini di bawah skema Penelitian Dosen Pemula. 


\section{REFERENSI}

Anggraini N. 2015. Efisiensi pada Usahatani Ubi Kayu di Kabupaten Lampung Tengah Provinsi Lampung. Bogor (ID): Institut Pertanian Bogor.

[BPS] Badan Pusat Statistik. 2019. Distribusi PDB Triwulanan Atas Dasar Harga Berlaku Menurut Lapangan Usaha (Persen), 2014-2018. Jakarta (ID): Badan Pusat Statistik.

Chonani SH, Prasmatiwi FE, Santoso H. 2014. Efisiensi Produksi dan Pendapatan Usahatani Cabai Merah di Kecamatan Metro Kibang Kabupaten Lampung Timur : Pendeketan Fungsi Produksi Frontier. JIIA. 2(2):95-102.

Coelli T, Rao DSP, Battese GE. 1998. An Introduction to Efficiency and Productivity Analysis. London (UK): Kluwer Academic Publishers.

Dinas Pertanian Provinsi Kepulauan Bangka Belitung. 2017. Jumlah Luas Tanam, Luas Panen, Produksi dan Produktivitas Cabai Merah di Kabupaten Bangka Tengah. Provinsi Kepulauan Bangka Belitung (ID): Dinas Pertanian.

Ellis F. 2003. Peasant Economics (Petani Gurem : Rumah Tangga Usahatani dan Pembangunan Pertanian). Diterjemahkan oleh Adi Sustanto dkk. Bayu Media dan UMM Press.

Gusmawati, Laapo A, Howara D. 2014. Analisis Kelayakan Usahatani Cengkeh di Desa Bou Kecamatan Sojol Kabupaten Donggala Provinsi Sulawesi Tengah. Agrotekbis. 2(3):325331.

[Kepementan] Keputusan Menteri Pertanian Republik Indonesia. 2016. Lokasi Pengembangan Kawasan Pertanian Nasional. Jakarta (ID): Kementerian Pertanian RI.

Mohapatra R. 2013. Farm Level Technical Efficiency in Paddy Production : A Translog Frontier Production Function Approach. International Journal of Advanced Research. 1(3):300-307.

Pranata GW, Damayanti L. 2016. Faktor-faktor yang Mempengaruhi Produksi Usahatani Cabai Merah Keriting di Desa Bulupountu Jaya Kecamatan Sigih Biromaru Kabupaten Sigi. Jurnal Agroland. 23(1):11-19.

Saptana, Daryanto A, Daryanto HK, Kuntjoro. 2010. Analisis Efisiensi Teknis Produksi Usahatani Cabai Merah Besar dan perilaku Petani dalam Menghadapi Risiko. Jurnal Agro Ekonomi. 28(2):153-188.

Saputra IMAD, Wenagama IW. 2019. Analisis Efisiensi Faktor Produksi Usahatani Cabai Merah di Desa Buahan Kecamatan Payangan Kabupaten Giayar. Jurnal Ekonomi Pembangunan Universitas Udayana. 8(1):31-60.

Sumaryanto W, Siregar M. 2003. Determinan Efisiensi Teknis di Lahan Sawah Irigasi. Jurnal Agro Ekonomi. 21(1):72-96.

Widyastuti. 2018. Respon Petani terhadap Program Peningkatan Produktivitas Cabai Merah (Capsicum annuum, L.) di Kabupaten Bangka Tengah. Balunijuk (ID): Universitas Bangka Belitung. 